\title{
Measurement of Kinetic Parameters for Biotransformation of Polycyclic Aromatic Hydrocarbons by Trout Liver S9 Fractions: Implications for Bioaccumulation Assessment
}

\author{
John W. Nichols, Melanie A. Ladd, and Patrick N. Fitzsimmons
}

\begin{abstract}
Introduction: In vitro substrate depletion methods developed by the pharmaceutical industry are being used with increasing frequency to support chemical bioaccumulation assessments for fish. However, the application of these methods to high $\log K_{\mathrm{ow}}$ chemicals poses special challenges.

Materials and Methods: Biotransformation of three polycyclic aromatic hydrocarbons (PAHs) was measured using trout liver S9 fractions. Studies were performed to evaluate the working lifetime of the S9 preparation, assess effects of chemical spiking solvents, and characterize the concentration-dependence of activity.

Results: Derived kinetic constants $\left(K_{\mathrm{M}}\right.$ and $\left.V_{\max }\right)$ suggested that the three PAHs (phenanthrene, pyrene and benzo[a]pyrene) are transformed by the same reaction pathway and indicated an inverse correlation between $K_{\mathrm{M}}$ and chemical $\log K_{\mathrm{ow}}$. Reaction rates were proportional to unbound chemical concentrations except when these concentrations approached saturating levels, providing a direct demonstration of the free chemical hypothesis.

Discussion: These findings suggest that previous in vitro work with high $\log K_{\mathrm{ow}}$ compounds has been conducted at inappropriately high substrate concentrations, resulting in underestimation of true in vivo activity. Preliminary calculations also indicate that PAH metabolism in fish may approach saturation during standardized in vivo testing efforts, potentially resulting in steady-state levels of accumulation greater than those that occur in a natural setting. Conclusion: The use of in vitro methods to predict metabolism impacts on chemical bioaccumulation in fish requires careful consideration of study conditions to ensure that measured rates of activity can be extrapolated with confidence to the intact animal.
\end{abstract}

Keywords: biotransformation, in vitro-in vivo extrapolation, bioaccumulation assessment, rainbow trout, fish

\section{Introduction}

$\boldsymbol{I}_{\mathrm{r}}$

N VITRO KINETIC STUDIES of biotransformation are often performed by measuring initial rates of product formation across a range of substrate concentrations. For a compound whose metabolism follows classical Michaelis-Menten kinetics, this approach yields an estimate of $K_{\mathrm{M}}$, the substrate concentration resulting in half-maximal activity, and $V_{\max }$, the maximum reaction velocity. Data obtained in this manner generally lend themselves to straightforward interpretation since the reaction usually involves one enzyme. An obvious drawback to this approach is the need to know in advance what the product of a reaction will be. In addition, many compounds are metabolized by multiple enzymes to several different products. Detailed information for one pathway may therefore provide an incomplete picture of a compound's overall transformation by an organism.

Alternatively, in vitro studies may be performed by monitoring the disappearance of parent compound. This substrate depletion approach, which does not require knowledge of metabolic pathways or products, was pioneered by the pharmaceutical industry to predict hepatic clearance of drug candidates. $^{1-3}$ When employed for this purpose, the assay is typically run at a starting substrate concentration known (or assumed) to be well below $K_{\mathrm{M}}$. These conditions generally result in log-linear depletion kinetics and yield a firstorder depletion rate constant $\left(k_{\mathrm{dep}} ; 1 / \mathrm{min}\right)$. Dividing $k_{\mathrm{dep}}$ by the protein ( $\mathrm{S} 9$ or microsomal fraction) or hepatocyte 
concentration gives the in vitro intrinsic clearance $\left(\mathrm{CL}_{\text {in vitro,int }} ; \mathrm{mL} / \mathrm{min} \cdot \mathrm{mg}\right.$ protein or $10^{6}$ cells $)$, which may be interpreted as the ratio $V_{\max } / K_{\mathrm{M}}$. The substrate depletion approach may also be used to estimate $K_{\mathrm{M}}$ and $V_{\max }$ by measuring initial reaction rates across a range of substrate concentrations. ${ }^{4}$ In this case, the derived parameters reflect the net result of all pathways operating on the compound of interest.

Substrate depletion methods have been adopted by ecotoxicologists to predict hepatic clearance of hydrophobic environmental contaminants by fish. ${ }^{5,6}$ Chemical accumulation in fish may be substantially reduced by biotransformation, ${ }^{7-9}$ but the rate of this activity is not easily predicted from chemical structure or simple physicochemical properties. In vitro assays are therefore used to obtain this information, which is then extrapolated to the whole animal and employed as an input to predictive models for chemical accumulation. In such cases, the principal concern is for elimination of the parent compound and not production of any specific metabolite. The use of a substrate depletion approach is therefore appropriate. Because they represent complete metabolizing systems, most of this research has been performed using liver S9 fractions or isolated hepatocytes.

To date, these studies have shown that incorporating in vitro metabolism data into predictive models for chemical accumulation substantially improves model performance; thus, predicted bioconcentration factors (BCFs; defined as the steady-state chemical concentration in a fish divided by that in water, assuming a water-only exposure) tend to be much closer to measured BCFs than are modeled predictions that assume no metabolism. ${ }^{10-14}$ Generally, however, there is a trend toward underprediction of apparent in vivo activity, which results in overprediction of observed bioaccumulation. This is particularly true when hepatic clearance is assumed to be controlled by unbound (free) chemical concentrations in vitro and in vivo.

Several explanations have been offered for these findings, including kinetic considerations that make bound chemicals available to metabolizing enzymes in the liver, ${ }^{15}$ and the possible contribution of extrahepatic metabolism. ${ }^{16}$ Active uptake into the hepatocyte may result in an unbound chemical concentration within the cell that is substantially higher than that in plasma. ${ }^{17}$ However, this process is unlikely to be important for most neutral chemicals, including those of concern for the majority of bioaccumulation assessments. Finally, it is possible that in vitro assays simply do not reflect true levels of in vivo intrinsic clearance.

The purpose of this study was to rigorously evaluate an in vitro assay (trout liver S9 fraction) that has been used by a number of research groups to predict in vivo hepatic clearance in fish. ${ }^{6,12-14}$ The questions evaluated in this study are relevant, however, to the use of other in vitro metabolizing systems (e.g., microsomes and suspended or plated hepatocytes). An optimized method was then employed to estimate $K_{\mathrm{M}}$ and $V_{\max }$ values for biotransformation of three polycyclic aromatic hydrocarbons (PAHs). To support this effort, we determined unbound chemical concentrations using a vial equilibration method. These findings yield a direct test of the free chemical hypothesis as it pertains to in vitro measurement of $\mathrm{PAH}$ metabolism and provide an improved basis for relating this information to chemical exposures experienced by fish in the wild and in standardized in vivo testing efforts.

\section{Materials and Methods}

\section{Chemicals}

Benzo[a]pyrene (BAP), phenanthrene (PHEN), pyrene (PYR), ethoxyresorufin, $p$-nitrophenol ( $p$-NP), and 1-chloro2,4-dinitrobenzene (CDNB) were purchased from SigmaAldrich. The reported purity for these chemicals was $>95 \%$. $\beta$-Nicotinamide adenine dinucleotide phosphate $(\beta$-NADPH; $>95 \%$ pure) was purchased from Oriental Yeast Co. Adenosine $3^{\prime}$-phosphate $5^{\prime}$-phosphosulfate (PAPS; $80 \%$ pure) was obtained from EMD Millipore (Calbiochem). All other chemicals and solvents were purchased from Sigma-Aldrich and were reagent grade or higher in quality.

\section{Animals}

Rainbow trout (Oncorhynchus mykiss) weighing $\sim 100 \mathrm{~g}$ were obtained from the USGS Upper Midwest Environmental Sciences Center and grown up to the size used in these studies. The fish were fed commercial trout chow (Classic Trout; Skretting) and maintained on a 16-hour light-8-h dark cycle at $11 \pm 1^{\circ} \mathrm{C}$. Water employed for fish holding was obtained directly from Lake Superior (single pass, sand filtered, and UV treated) and had the following characteristics: alkalinity, 41-44 mg/L as $\mathrm{CaCO}_{3}$; $\mathrm{pH}, 7.6-7.8$; total ammonia, $<1 \mathrm{mg} / \mathrm{L}$; and dissolved oxygen, $85 \%-100 \%$ of saturation.

The fish used in this study were $\sim 1.5$ years old at the time of sacrifice and had not previously undergone a spawning cycle. Their sexual maturity was evaluated by calculating the gonadosomatic index (GSI) for each animal (equal to the mass of gonads/mass of body $\times 100$ ). GSI values ranged from 0.03 to 0.05 for males and 0.16 to 0.22 for females. A comparison of these values with published information for trout ${ }^{18,19}$ indicates that the fish were in very early stages of sexual maturation (stage I/II for males and II/III for females). Previous work has shown that hepatic biotransformation rates in sexually immature trout vary little if at all with gender. $^{20,21}$

\section{Preparation and characterization of liver S9 fractions}

Liver S9 fractions were prepared using procedures given by Johanning et al. ${ }^{22}$ Briefly, fish were killed with an overdose of 3-aminobenzoate methanesulfonate (MS 222; $300 \mathrm{mg} / \mathrm{L})$ buffered with $\mathrm{NaHCO}_{3}(900 \mathrm{mg} / \mathrm{L})$. Previous work has shown that MS 222 used in this manner does not impact cytochrome P450 (CYP) protein levels or measured levels of CYP activity. ${ }^{23,24}$ The body cavity was opened, exposing the liver, and the hepatic vein was severed to permit a free flow of blood. The liver was then cleared of blood by perfusion with Hanks' balanced salt solution $\left(\mathrm{CaCl}_{2}-\right.$, $\mathrm{MgSO}_{4}-$, and phenol red-free) supplemented with $2.3 \mathrm{mM}$ ethylenediaminetetraacetic acid (EDTA) and $10 \mathrm{mM}$ HEPES.

Livers were individually homogenized in two volumes of homogenization buffer using 4-5 strokes of a PotterElvehjem mortar and pestle. The homogenization buffer (pH 7.80 \pm 0.05 ) consisted of $150 \mathrm{mM} \mathrm{KCl,} 50 \mathrm{mM}$ Tris, $1 \mathrm{mM}$ dithiothreitol, $2 \mathrm{mM}$ EDTA, and $250 \mathrm{mM}$ sucrose. Pooled homogenates, representing 5-6 fish of mixed sex, were centrifuged at $13,000 \mathrm{~g}$ for 20 minutes at $4^{\circ} \mathrm{C}$. Aliquots $(0.5 \mathrm{~mL})$ of the $\mathrm{S} 9$ fraction were then flash-frozen in liquid 
$\mathrm{N}_{2}$ and stored at $-80^{\circ} \mathrm{C}$. Detailed information pertaining to each pool of test material is shown in Table 1.

The metabolic activity of S9 fractions was evaluated by performing a set of assays using model substrates for CYP1A, UDP-glucuronosyltransferase (UGT), and glutathione- $S$ transferase (GST). CYP1A activity was characterized by measuring the rate of 7-ethoxyresorufin O-dealkylation (EROD assay). ${ }^{25}$ UGT activity was characterized by measuring glucuronidation of $p$-NP. ${ }^{26}$ GST activity was assessed by measuring glutathione conjugation of $\mathrm{CDNB} .^{27}$ All assays were performed using saturating substrate concentrations at the physiological temperature $\left(11 \pm 1^{\circ} \mathrm{C}\right)$ and $\mathrm{pH}(7.80 \pm$ 0.05 ) for trout. Additional details pertaining to these assays are given elsewhere. ${ }^{28}$ The protein content of each pooled sample was measured using Peterson's modification of the Lowry method (Sigma technical bulletin TP0300). Total CYP content was determined using a dithionite difference spectroscopy method ${ }^{29}$ modified for use with fish. ${ }^{30}$

\section{Method optimization}

Substrate depletion experiments were performed at $11 \pm 1^{\circ} \mathrm{C}$ by spiking PHEN, PYR, or BAP into $1-\mathrm{mL}$ reaction mixtures containing $100 \mathrm{mM}$ potassium phosphate buffer $(\mathrm{pH} \quad 7.80 \pm 0.05), 2 \mathrm{mM} \quad \beta-\mathrm{NADPH}, 2 \mathrm{mM}$ uridine $5^{\prime}$ diphosphoglucuronic acid (UDPGA), $0.1 \mathrm{mM}$ PAPS, and $5 \mathrm{mM}$ reduced L-glutathione. Alamethicin, a pore-forming peptide, was added to support UGT activity. ${ }^{26}$ The amount of alamethicin was adjusted as described below. Buffer, S9 protein, and alamethicin were mixed and preincubated on ice for 15 minutes. Except where noted, all reactions were performed using $1 \mathrm{mg} / \mathrm{mL} \mathrm{S} 9$ protein and were initiated by adding substrate in acetone carrier $(0.5 \%$ [v/v] final concentration). The reactions were terminated by transferring $100-$ $\mu \mathrm{L}$ aliquots of the reaction mixture into $300 \mu \mathrm{L}$ of ice-cold acetonitrile $(\mathrm{ACN})$. These samples were vigorously mixed and centrifuged ( $3000 \mathrm{~g}, 6$ minutes at $4^{\circ} \mathrm{C}$ ) to pellet protein. Supernatants were transferred to amber gas chromatography vials and stored at $4^{\circ} \mathrm{C}$. All samples were analyzed within 24 hours.

The kinetics of substrate depletion may be impacted by a loss of enzyme activity over time. This is a special concern when dealing with fish because measured rates of activity are often much lower than those in mammals for the same biotransformation reaction. Thus, longer periods of time may be required to obtain measurable depletion of a parent substance. To investigate the effect of time on clearance of the three test compounds, we prepared incubation mixtures and then held them in a water bath at $11^{\circ} \mathrm{C}$ for varying lengths of time (referred to here as the holding time) before starting the reaction. The amount of alamethicin added to these reactions was $25 \mu \mathrm{g} / \mathrm{mL}$. Duplicate reactions were initiated immediately ( 0 hours) after placing the vessels in the water bath (after thermal equilibration) and again after 0.5 , 1,2 , and 3 hours.

To facilitate their introduction and promote rapid distribution and dissolution, hydrophobic compounds are often spiked into in vitro assays using an organic solvent. However, the solvent itself may impact the measured activity of the system. Preliminary studies were conducted by spiking PHEN into the S9 system using $0.5 \%$ or $2 \%(\mathrm{v} / \mathrm{v}) \mathrm{ACN}$ or acetone. Depletion rates obtained using acetone were consistently faster than those measured using ACN (data not shown). In each case, however, the dataset suggested a solvent concentration effect. To evaluate this question further, we performed triplicate depletion assays with PHEN, introduced using different amounts of acetone. These assays were again performed using $25 \mu \mathrm{g} / \mathrm{mL}$ alamethicin. The final concentration of acetone was varied from $0.25 \%$ to $5 \%(\mathrm{v} / \mathrm{v})$.

The introduction of alamethicin to the $\mathrm{S} 9$ system requires the use of a small amount of solvent (typically methanol). This solvent, like that used to spike in test chemicals, may have negative effects on enzyme activity. Alternatively, alamethicin itself may impact some nonglucuronidation reactions. Triplicate depletion assays with PHEN were therefore run at alamethicin concentrations ranging from

Table 1. Characterization of Pooled Trout Liver S9 Fractions Used in Various Experiments

\begin{tabular}{|c|c|c|c|c|}
\hline & \multicolumn{4}{|c|}{ Experiments performed using each pool of $S 9$ protein $^{\mathrm{a}}$} \\
\hline & $\begin{array}{l}\text { Pool 1: Effect } \\
\text { of incubation time }\end{array}$ & $\begin{array}{l}\text { Pool 2: Protein } \\
\text { dependence and effect } \\
\text { of alamethicin }\end{array}$ & $\begin{array}{l}\text { Pool 3: Substrate } \\
\text { concentration dependence } \\
\text { and effect of acetone }\end{array}$ & $\begin{array}{l}\text { Pool 4: Chemical } \\
\text { binding }\end{array}$ \\
\hline Fish number & 20,49 & 10,49 & 40,19 & $30^{t}, 3$ \\
\hline Fish body wt. (g) & $349 \pm 50$ & $382 \pm 39$ & $420 \pm 67$ & $315 \pm 46$ \\
\hline HSI $(\%)$ & $0.98 \pm 0.14$ & $1.11 \pm 0.06$ & $0.92 \pm 0.10$ & $1.01 \pm 0.09$ \\
\hline GSI, males (\%) & $0.04 \pm 0.01$ & 0.03 & $0.04 \pm 0.01$ & $0.05 \pm 0.02$ \\
\hline GSI, females (\%) & $0.16 \pm 0.08$ & $0.19 \pm 0.11$ & 0.22 & $0.19 \pm 0.07$ \\
\hline Protein content $(\mathrm{mg} / \mathrm{mL})$ & $23.9 \pm 0.04$ & $24.2 \pm 0.8(4)$ & $25.6 \pm 0.9$ (4) & $24.1 \pm 0.1(3)$ \\
\hline CYP content (pmol/g liver) & $4351 \pm 232$ & $3771 \pm 280(4)$ & $3755 \pm 256$ (4) & $\mathrm{N} / \mathrm{P}$ \\
\hline $\begin{array}{l}\text { EROD activity }(\mathrm{pmol} / \\
\mathrm{min} \cdot \mathrm{mg} \text { protein })\end{array}$ & $4.5 \pm 0.2(4)$ & $5.7 \pm 0.3(4)$ & $6.0 \pm 0.3(4)$ & $6.1 \pm 0.2(3)$ \\
\hline $\begin{array}{l}\text { UGT activity (pmol/ } \\
\text { min } \cdot \text { mg protein) }\end{array}$ & $978 \pm 46(4)$ & $1074 \pm 36(4)$ & $678 \pm 115(4)$ & $804 \pm 25(4)$ \\
\hline $\begin{array}{l}\text { GST activity }(\mathrm{nmol} / \\
\mathrm{min} \cdot \mathrm{mg} \text { protein })\end{array}$ & $538 \pm 14(4)$ & $698 \pm 36(4)$ & $466 \pm 9(4)$ & $553 \pm 47(3)$ \\
\hline
\end{tabular}

${ }^{a}$ Values given in parentheses indicate the number of replicated determinations.

HSI, hepatosomatic index; GSI, gonadosomatic index; EROD, 7-ethoxyresorufin- $O$-deethylase; UGT, UDP-glucuronosyltransferase; GST, glutathione-S-transferase; CYP, cytochrome P450; N/P, not performed. 
10 to $50 \mu \mathrm{g} / \mathrm{mL}$, which is the concentration range typically employed for research on mammalian microsomal fractions. ${ }^{31,32}$ To limit the confounding influence of methanol addition, all of these assays were performed using $0.25 \%$ methanol (final concentration $[\mathrm{v} / \mathrm{v}]$ ). Additional assays were then performed without added methanol or alamethicin or with $0.25 \%$ methanol only. The results suggested that 25 or $50 \mu \mathrm{g} / \mathrm{mL}$ alamethicin may impact PAH metabolism (see below). Thus, all subsequent assays were run at a constant ratio of $10 \mu \mathrm{g}$ alamethicin/mg S9 protein, with a final methanol concentration of $0.1 \%$.

\section{Determination of kinetic parameters, $\mathrm{K}_{\mathrm{M}}$ and $\mathrm{V}_{\max }$}

Michaelis-Menten constants $\left(K_{\mathrm{M}}\right.$ and $\left.V_{\max }\right)$ for the disappearance of PHEN, PYR, and BAP were determined by performing triplicate depletion experiments at six or seven substrate concentrations. Taking into account the dilution factor associated with sampling (fourfold) as well as the need to measure substrate depletion over time, the lowest tested concentrations were designed to be $\sim 30$ times greater than analytical detection limits. Under these conditions, substrate concentrations in sample extracts from later sampling times were 3-5 times higher than the limit of detection. Preliminary experiments were performed to develop sampling protocols for each of the tested concentrations. The goal was to develop a protocol in which $10 \%-50 \%$ of substrate was depleted across 5-8 sampling intervals. The outcome was a unique set of sampling times for each of the tested concentrations.

\section{Effect of S9 protein concentration on in vitro clearance}

The effect of S9 protein concentration on in vitro clearance was evaluated by measuring depletion rates for all three PAHs at protein concentrations ranging from 0.1 to $2.0 \mathrm{mg} / \mathrm{mL}$. These experiments were performed at fixed substrate concentrations of 0.02, 0.006, and $0.002 \mu \mathrm{M}$ for PHEN, $\mathrm{PYR}$, and BAP, respectively. In each case, this starting concentration was at least 10-fold lower than the $K_{\mathrm{M}}$ value determined at $1 \mathrm{mg} / \mathrm{mL}$ S9 protein (see Determination of $K_{\mathrm{M}}$, $V_{\max }$, and $\mathrm{CL}_{\text {in vitro,int }}$ section). Binding effects on clearance were then investigated by measuring unbound chemical fractions at the same tested protein concentrations.

\section{Measurement of unbound chemical fractions using a vial equilibration method}

Bound and unbound (free) chemical fractions in buffer solutions containing $0.1-2.0 \mathrm{mg} / \mathrm{mL} \mathrm{S} 9$ protein were determined using a vial equilibration method. ${ }^{33,34}$ The freely dissolved chemical concentration was controlled by equilibrium partitioning from silicone, while the total concentration in solution was measured as the dependent variable. Silicone polymer (500 mg; MED-4210, Factor II) was cast into 10-mL glass vials and allowed to cure. The silicone was then loaded with PHEN and PYR (tested together), or BAP, using methanol as the carrier solvent. ${ }^{34}$ Binding of PHEN and PYR was determined using five vials, sampled in triplicate, for each of the five S9 protein concentrations tested (25 vials total). Anticipating that BAP would present a special challenge due to its high $\log K_{\text {ow }}$ value, seven vials sampled in triplicate were used to measure binding (35 vials total).
Vials containing $2 \mathrm{~mL}$ of potassium phosphate buffer $(100 \mathrm{mM})$ or $\mathrm{S} 9$ suspension were incubated at $11^{\circ} \mathrm{C}$ on an orbital shaker (350 rpm; IKA Vibrax VXR; IKA Works). Preliminary studies were conducted to determine the length of time needed to achieve equilibrium and the amount of rinsing required to obtain stable buffer values after the introduction of S9 protein. For PHEN and PYR, buffer samples were equilibrated for 4 hours, while samples containing S9 protein were equilibrated for 24 hours. Following the introduction of S9 protein, these vials were rinsed 20 times with $2 \mathrm{~mL}$ of deionized water (Milli-Q; Millipore), accompanied each time by vigorous shaking. For BAP, buffer samples were equilibrated for 24 hours, while samples containing S9 protein were equilibrated for 72 hours. Following the introduction of S9 protein, these vials were rinsed 35 times with $2 \mathrm{~mL}$ of deionized water. The $\mathrm{S} 9$ fractions were inactivated before the binding studies by withholding cofactors and allowing the samples to stand at $\sim 25^{\circ} \mathrm{C}$ for 24 hours before use. ${ }^{30}$

Following equilibration, subsamples containing buffer or S9 suspension were pipetted into ACN (twofold dilution for buffer samples, fivefold dilution for S9). Precipitated protein in the $S 9$ samples was pelleted by centrifugation at 3000 $g$ for 5 minutes. The resulting supernatant was then diluted as needed with $75 \%$ ACN $/ 25 \%$ water (v/v), depending on the test compound and $\mathrm{S} 9$ concentration. The freely dissolved chemical fraction $\left(f_{\mathrm{u}}\right)$ in samples containing $\mathrm{S} 9$ protein was calculated as $C_{\text {buffer }} / C_{\text {tot }}$, where $C_{\text {tot }}$ refers to the measured $\mathrm{PAH}$ concentration for an individual vial containing S9 protein and $C_{\text {buffer }}$ is the average of buffer values determined for the same vial before and after the introduction of $S 9$ protein. The bound fraction of chemical was calculated as $1-f_{\mathrm{u}}$.

\section{Analytical methods}

A high-performance liquid chromatography (HPLC) method was used to measure PHEN, PYR, and BAP. Samples were injected onto an Agilent 1260 HPLC system equipped with a fluorescence detector. Chromatography was performed with a reverse-phase Hypersil Green PAH column ( $3 \mu \mathrm{m}, 100 \times 2.1 \mathrm{~mm}$; Thermo Fisher Scientific). Solvent A consisted of $90 \%$ water (Milli-Q; Millipore) and $10 \%$ ACN. Solvent B consisted of 5\% water and 95\% ACN. The solvents were run isocratically at a flow rate of $0.7 \mathrm{~mL} / \mathrm{min}$, but the proportions of solvents $\mathrm{A}$ and $\mathrm{B}$ were changed for each PAH to optimize run time and peak symmetry. The excitation/emission wavelengths (nm) were 260/350 (PHEN), 237/390 (PYR), and 255/420 (BAP). The limits of detection for PHEN, PYR, and BAP were about $0.5,0.2$, and $0.1 \mathrm{nM}$, respectively. The PAH content in the S9 extracts was quantified by comparing peak areas with those of known standards.

\section{Data analysis}

A linear equation was fitted to $\log _{10}$-transformed data from each substrate depletion experiment to calculate a first-order depletion rate constant $\left(k_{\mathrm{dep}} ; 1 / \mathrm{h}\right.$, equal to $-2.3 \times$ slope $)$. This equation was fitted to all data points if the data exhibited loglinear kinetics. If the data exhibited a nonlinear pattern, $k_{\text {dep }}$ was calculated only from the initial log-linear phase of the depletion curve.

The Michaelis-Menten kinetic parameters, $K_{\mathrm{M}}$ and $V_{\max }$, were estimated using the method given by Obach and 
Reed-Hagen. ${ }^{4}$ This procedure involves measuring the rate of substrate depletion across a range of substrate concentrations. The $k_{\mathrm{dep}}$ values determined at each substrate concentration $([\mathrm{S}] ; \mu \mathrm{M})$ are then fitted to an equation of the form

$$
k_{\mathrm{dep}}=k_{\mathrm{dep}([\mathrm{S}] \rightarrow 0)} \times\left(1-[\mathrm{s}] /\left([\mathrm{s}]+K_{\mathrm{M}}\right)\right)
$$

where $K_{\mathrm{M}}$ is the [S] at which $k_{\mathrm{dep}}$ is half-maximal and $k_{\mathrm{dep}([\mathrm{S}] \rightarrow 0)}$ is the first-order depletion rate constant expected at very low substrate concentrations. Although initially developed as an empirical relationship, subsequent work has shown that Equation (1) is theoretically sound. ${ }^{35}$ Once the value of $K_{\mathrm{M}}$ has been estimated, $V_{\max }$ for the reaction may be calculated by rearrangement of Equation (1). Ideally, $K_{\mathrm{M}}$ and $V_{\max }$ are determined from experiments where the total extent of substrate depletion (\% of starting value) is $<10 \%$. However, errors in their estimation are small $(<15 \%)$ if $<50 \%$ of substrate has been consumed. ${ }^{35}$ Estimated rates of $\mathrm{CL}_{\text {in vitro, int }}$ were calculated as $k_{\operatorname{dep}([\mathrm{S}] \rightarrow 0)}$ divided by the $\mathrm{S} 9$ protein concentration in the reaction vessel. Identical $\mathrm{CL}_{\text {in vitro,int }}$ values may be calculated from the ratio $V_{\text {max }} / K_{\mathrm{M}}$ after unit conversion.

\section{Results}

\section{Characterization of pooled trout liver S9 fraction}

Pooled S9 fractions were characterized to determine their protein and CYP content, as well as their activity toward a set of standard substrates (Table 1). Measured EROD and UGT activities ranged from 4.5 to $6.1 \mathrm{pmol} / \mathrm{min} \cdot \mathrm{mg}$ protein and $678-1074 \mathrm{pmol} / \mathrm{min} \cdot \mathrm{mg}$ protein, respectively. The range of measured GST activities was $466-698 \mathrm{nmol} / \mathrm{min} \cdot \mathrm{mg}$ protein. Given the genetic diversity of the sampled fish population, these modest differences in activity among S9 pools are expected. Similar EROD, UGT, and GST values have been reported for the same strain of trout, ${ }^{28}$ suggesting that the pooled S9 fractions possessed representative levels of activity.

\section{Method optimization}

To investigate the time dependence of in vitro activity, freshly thawed liver S9 fractions were held for varying lengths of time at $11^{\circ} \mathrm{C}$ before starting a depletion experiment. Figure 1A shows the complete set of results for PYR. In this and other figures showing substrate depletion data, concentrations depicted at each time point represent the mean \pm standard deviation (SD) of individual values from replicate assays run in parallel. The plotted curves were then developed using these mean values and do not represent the results of any single assay. The means \pm SDs of fitted $k_{\text {dep }}$ values for each set of assays are given in Table 2 .

Mean $k_{\text {dep }}$ values for all three compounds after $0.5,1,2$, and 3 hours of holding time were divided by the initial (0 hours) reaction rate to express activity as a \% of initial (Fig. 1B). The results show that in vitro activity declined markedly with holding time. For BAP, this decrease was nearly linear with holding time and resulted in 15\%-20\% loss of starting activity per hour. The observed decrease in activity was even greater for PHEN and PYR, but was somewhat nonlinear with holding time. In either case, $>60 \%$ of initial activity was lost after 3 hours of holding time. However, the rate of decrease in activity was greatest during the first hour of sample holding, declining thereafter.
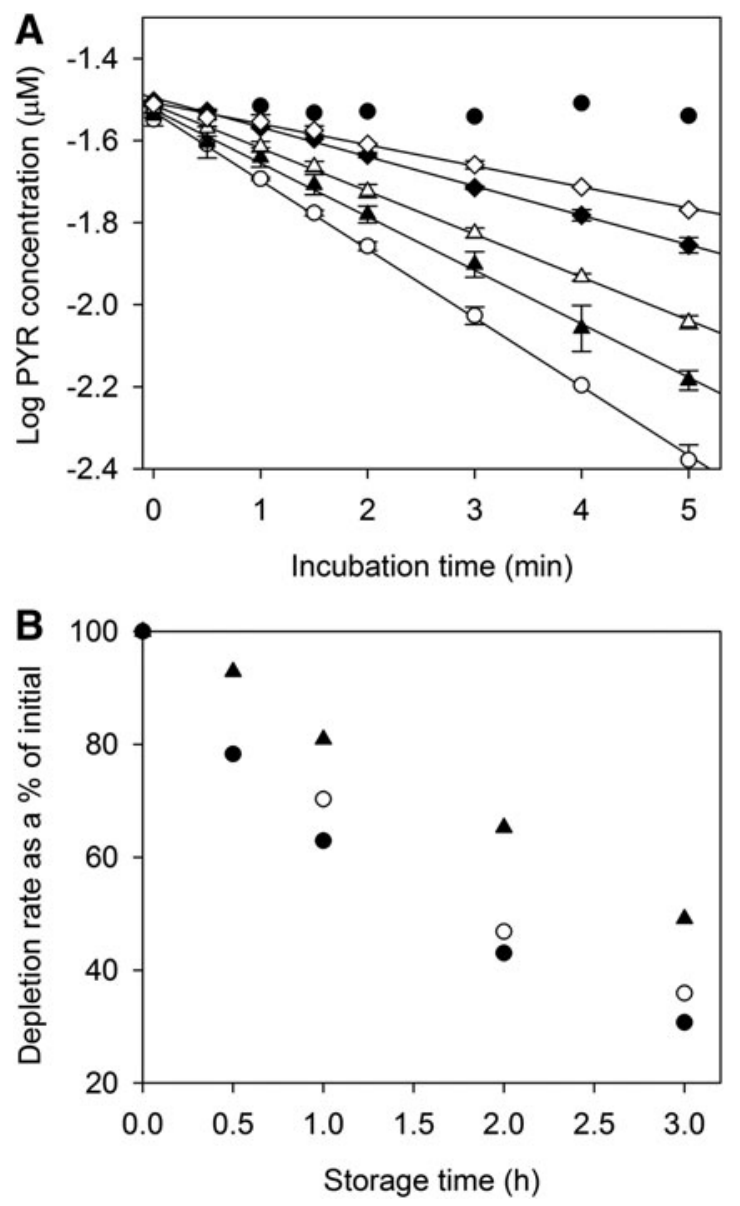

FIG. 1. Effect of storage time on biotransformation of PHEN, PYR, and BAP by trout liver S9 fractions. (A) Depletion curves for PYR obtained by storing $\mathrm{S} 9$ fractions at $11^{\circ} \mathrm{C}$ for varying lengths of time before starting the reaction: open circles -0 hours; solid triangles- 0.5 hours; open triangles-1.0 hours; solid diamonds-2 hours; open diamonds - 3 hours; solid dots-inactivated controls. Each point represents the mean $\pm S D$ of values determined in duplicate depletion assays. (B) Data for all three chemicals. Depletion rates are expressed as the \% of initial ( 0 hours) activity: solid dots-PYR; open circles-PHEN; solid triangles-BAP. PHEN, phenanthrene; PYR, pyrene; BAP, benzo $[a]$ pyrene; SD, standard deviation.

The effect of acetone on depletion of PHEN is shown in Figure 2 . Mean $k_{\mathrm{dep}}$ values differed significantly among the treatment groups (one-way analysis of variance [ANOVA], $p<0.05)$. Using the Newman-Keuls multiple range test, reaction rates measured using $0.25 \%$ and $0.5 \%$ acetone were shown to be statistically indistinguishable, while those generated using higher concentrations of acetone were significantly lower (Table 2).

Alamethicin had a concentration-dependent effect on PHEN metabolism (Fig. 3). The highest average rate of activity was obtained at $0 \mu \mathrm{g} / \mathrm{mL}$ alamethicin and $0 \%$ methanol and was considered to be a control value. Significant reductions in activity were determined for assays performed using 10,25 , or $50 \mathrm{mg} / \mathrm{mL}$ alamethicin (one-way ANOVA, followed by Dunnett's test, $p<0.05$; Table 2). Addition of $0.25 \%$ methanol alone also had a significant negative impact on measured activity. 
Table 2. Fitted Depletion Rate Constants $\left(k_{\text {dep }} ; 1 / \mathrm{h}\right)$ From S9 Optimization Studies

\begin{tabular}{|c|c|c|c|}
\hline & Phenanthrene & Pyrene & Benzo[a]pyrene \\
\hline \multicolumn{4}{|c|}{ Incubation time (hours) ${ }^{\mathrm{a}}$} \\
\hline 0 & $1.76 \pm 0.03$ & $23.00 \pm 0.99$ & $36.58 \pm 0.62$ \\
\hline 0.5 & - & $18.00 \pm 0.54$ & $33.97 \pm 1.22$ \\
\hline 1 & $1.24 \pm 0.00$ & $14.47 \pm 0.09$ & $29.59 \pm 0.67$ \\
\hline 2 & $0.82 \pm 0.01$ & $9.88 \pm 0.49$ & $23.91 \pm 0.40$ \\
\hline 3 & $0.63 \pm 0.01$ & $7.07 \pm 0.40$ & $17.95 \pm 0.78$ \\
\hline \multicolumn{4}{|c|}{ Acetone spiking solvent $(\%)^{\mathrm{b}}$} \\
\hline 0.25 & $1.73 \pm 0.05^{\mathrm{c}}$ & & \\
\hline 0.5 & $1.77 \pm 0.02^{\mathrm{c}}$ & & \\
\hline 1.0 & $1.49 \pm 0.04^{\mathrm{d}}$ & & \\
\hline 2.0 & $0.91 \pm 0.03^{\mathrm{e}}$ & & \\
\hline 5.0 & $0.36 \pm 0.02^{\mathrm{f}}$ & & \\
\hline \multicolumn{4}{|c|}{ Alamethicin/methanol ${ }^{\mathrm{b}}$} \\
\hline $0 \mu \mathrm{g} / \mathrm{mL} / 0 \%$ & $2.72 \pm 0.02$ & & \\
\hline $0 \mu \mathrm{g} / \mathrm{mL} / 0.25 \%$ & $2.52 \pm 0.01 * * *$ & & \\
\hline $10 \mu \mathrm{g} / \mathrm{mL} / 0.25 \%$ & $2.43 \pm 0.02 * * *$ & & \\
\hline $25 \mu \mathrm{g} / \mathrm{mL} / 0.25 \%$ & $2.20 \pm 0.03 * * *$ & & \\
\hline $50 \mu \mathrm{g} / \mathrm{mL} / 0.25 \%$ & $1.81 \pm 0.03 * * *$ & & \\
\hline
\end{tabular}

${ }^{\mathrm{a}}$ The nominal starting concentrations of phenanthrene, pyrene, and benzo[a]pyrene were $0.045,0.03$, and $0.005 \mu \mathrm{M}$, respectively.

${ }^{\mathrm{b}}$ The nominal starting concentration of phenanthrene was $0.035 \mu \mathrm{M}$.

${ }^{\mathrm{c}-\mathrm{f}}$ Denotes sample means that differ statistically from one another, $p<0.01$.

***Significantly different from the control mean $(0 \mu \mathrm{g} / \mathrm{mL}$ alamethicin $/ 0 \%$ methanol $), p<0.01$.

\section{Effect of substrate concentration on the shape of substrate depletion curves}

Initial rates of depletion for PHEN, PYR, and BAP depended strongly on starting substrate concentration (Fig. 4). For PYR and BAP, the kinetics of depletion appeared to be log-linear at both high and low starting concentrations, while depletion curves generated for intermediate concentrations tended to curve downward, indicating an increase in enzyme turnover. Log-linear depletion curves were observed for PHEN at all tested substrate concentrations.

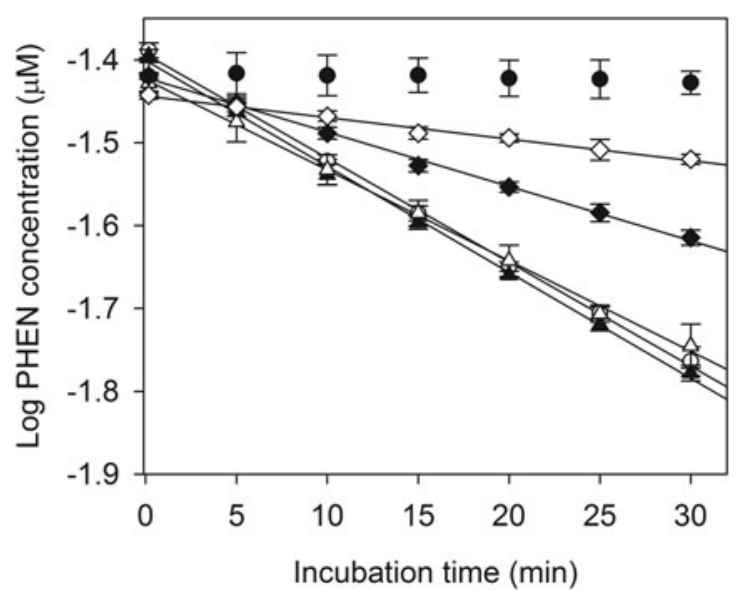

FIG. 2. Effect of acetone, used as a spiking solvent, on biotransformation of PHEN by trout liver S9 fractions. Each point represents the mean \pm SD of data from triplicate depletion assays. Open circles- $0.25 \%$ acetone; solid triangles$0.5 \%$ acetone; open triangles $-1.0 \%$ acetone; solid diamonds $-2.0 \%$ acetone; open diamonds $-5.0 \%$ acetone; solid dots-inactivated controls.
Determination of $\mathrm{K}_{M}, \mathrm{~V}_{\text {max }}$, and $\mathrm{CL}_{\text {in vitro,int }}$

Fitted $k_{\text {dep }}$ values for PHEN, PYR, and BAP exhibited the sigmoid relationship with [S] predicted by Equation (1) (Fig. 5). The kinetic parameters $K_{\mathrm{M}}, V_{\max }$, and $\mathrm{CL}_{\text {in vitro,int, }}$, determined by fitting Equation (1) to these datasets, are given in Table 3. Estimated $K_{\mathrm{M}}$ values for the three test compounds varied by a factor of 17 and tended to decrease with increasing chemical $\log K_{\text {ow }}$. In contrast, estimated $V_{\max }$ values were quite similar, varying by less than a factor of 2 .

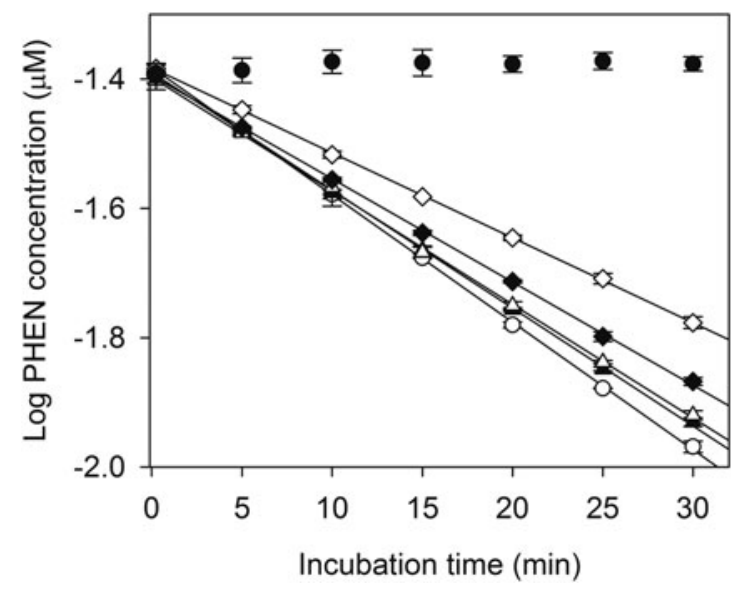

FIG. 3. Effect of alamethicin and methanol on biotransformation of PHEN by trout liver S9 fractions. Each point represents the mean $\pm S D$ of data from triplicate depletion assays. Open circles $-0 \mu \mathrm{g} / \mathrm{mL}$ alamethicin $/ 0 \%$ methanol; solid triangles $-0 \mu \mathrm{g} / \mathrm{mL}$ alamethicin $/ 0.25 \%$ methanol; open triangles- $10 \mu \mathrm{g} / \mathrm{mL}$ alamethicin $/ 0.25 \%$ methanol; solid diamonds $-25 \mu \mathrm{g} / \mathrm{mL}$ alamethicin $/ 0.25 \%$ methanol; open diamonds- $50 \mu \mathrm{g} / \mathrm{mL}$ alamethicin $/ 0.25 \%$ methanol; solid dots-inactivated controls. 

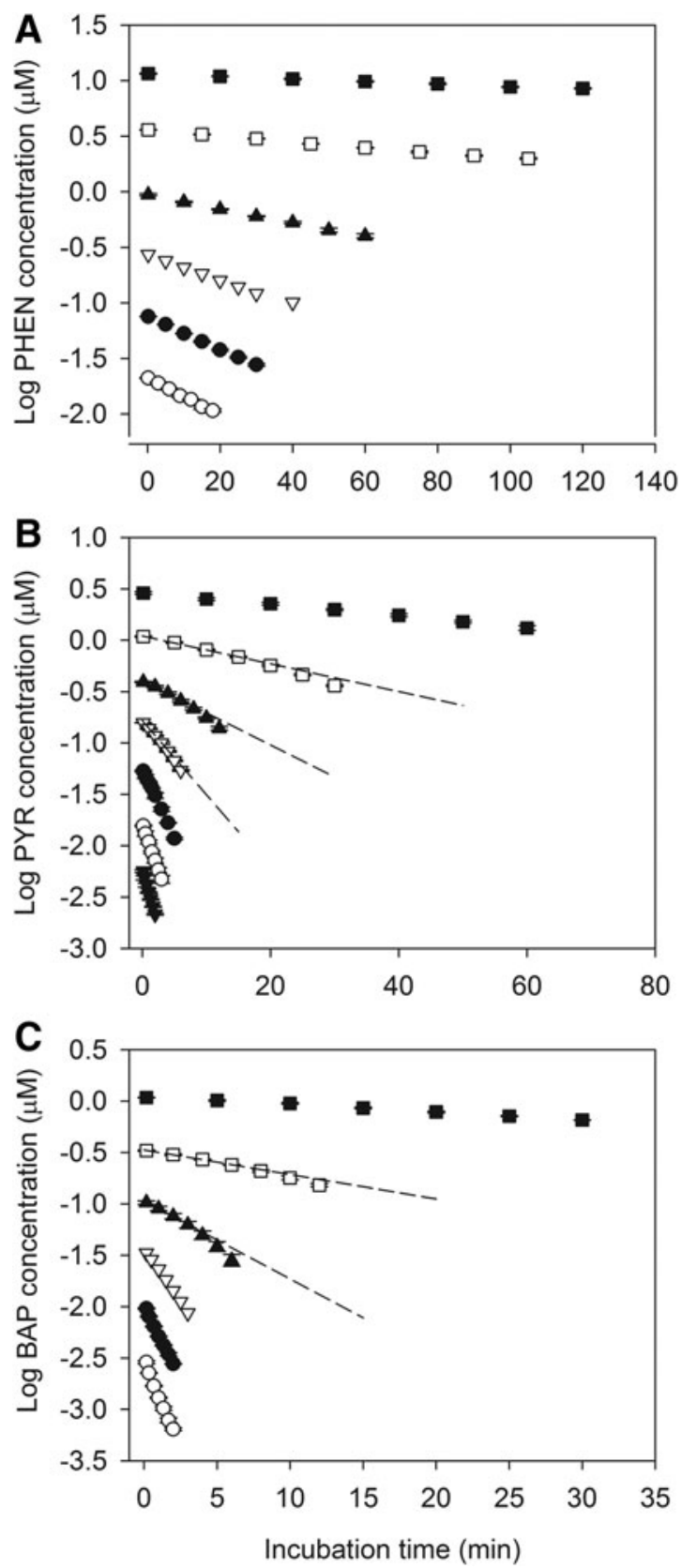

FIG. 4. Effect of starting substrate concentration on biotransformation of PHEN (A), PYR (B), and BAP (C). Each point represents the mean \pm SD of data from triplicate depletion assays. (A) Open circles- $-0.021 \mu \mathrm{M}$; solid dots$0.075 \mu \mathrm{M}$; open inverted triangles $-0.27 \mu \mathrm{M}$; solid triangles- $0.94 \mu \mathrm{M}$; open squares-3.61 $\mu \mathrm{M}$; solid squares$11.58 \mu \mathrm{M}$. (B) Inverted solid triangles $-0.0056 \mu \mathrm{M}$; open circles- $0.016 \mu \mathrm{M}$; solid dots $-0.053 \mu \mathrm{M}$; open inverted triangles $-0.16 \mu \mathrm{M}$; solid triangles $-0.39 \mu \mathrm{M}$; open squares- $1.09 \mu \mathrm{M}$; solid squares-2.88 $\mu \mathrm{M}$. (C) Open circles $-0.0029 \mu \mathrm{M}$; solid dots $-0.0096 \mu \mathrm{M}$; open inverted triangles $-0.033 \mu \mathrm{M}$; solid triangles $-0.10 \mu \mathrm{M}$; open squares $-0.33 \mu \mathrm{M}$; solid squares $-1.08 \mu \mathrm{M}$.
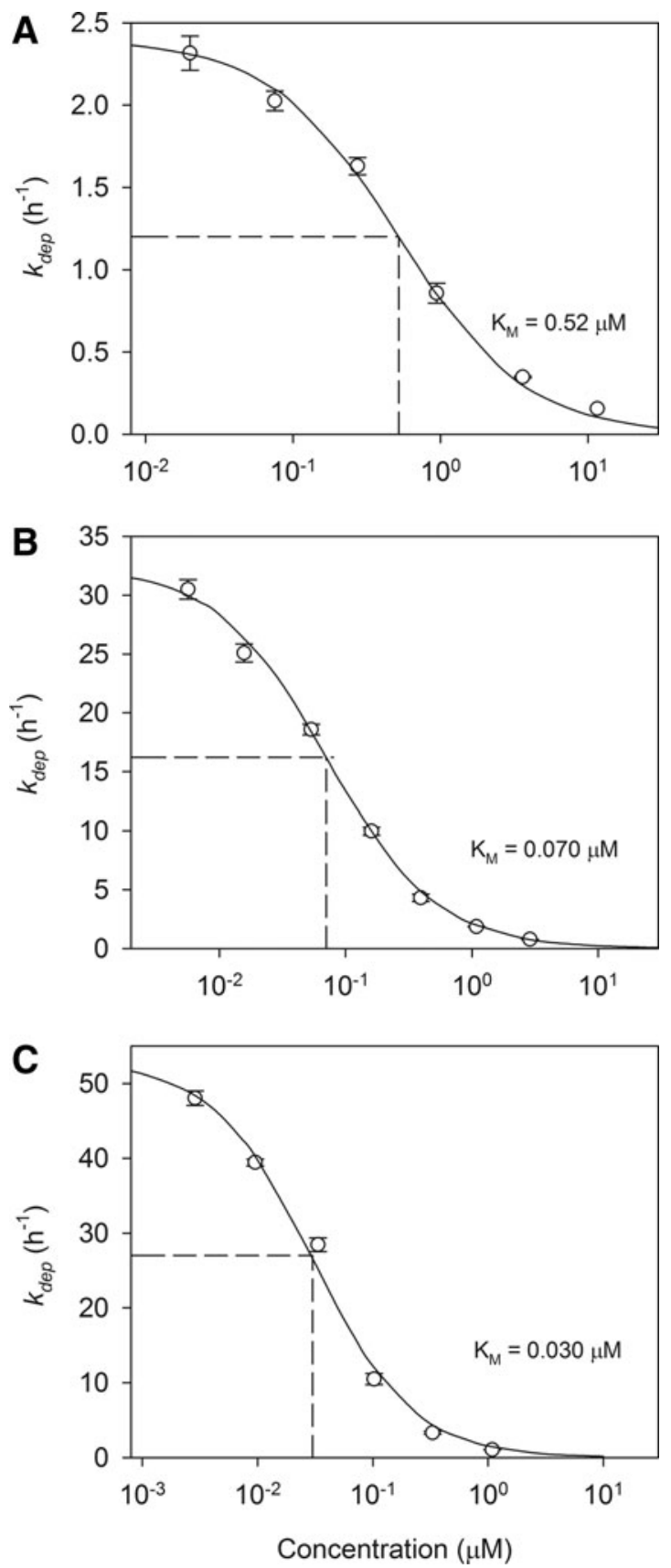

FIG. 5. Determination of Michaelis-Menten affinity constants $\left(K_{\mathrm{M}}\right)$ for biotransformation of PHEN (A), PYR (B), and BAP (C) by trout liver S9 fractions. Solid lines were obtained by fitting Equation (1) to initial depletion rates $\left(k_{\mathrm{dep}}\right)$ determined at different substrate concentrations. Each point represents the mean $\pm \mathrm{SD}$ of $k_{\mathrm{dep}}$ values from triplicate depletion assays.

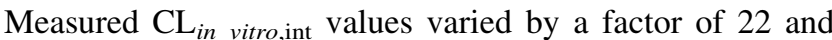
tended to increase with chemical $\log K_{\text {ow }}$.

In vitro binding of PHEN, PYR, and BAP

Chemical binding in the S9 system was highly dependent on protein concentration (Fig. 6A-C). When the data were plotted as the bound/free ratio $\left(1-f_{\mathrm{u}} / f_{\mathrm{u}}\right)$ versus $\mathrm{S} 9$ protein, 
Table 3. Kinetic Parameters for IN Vitro Biotransformation of Phenanthrene, Pyrene, AND Benzo[ $a]$ PyRENE By Trout LiVER S9 Fractions

\begin{tabular}{lccc}
\hline & Phenanthrene & Pyrene & Benzo[a]pyrene \\
\hline $\log K_{\mathrm{Ow}}^{\mathrm{a}}$ & 4.47 & 4.88 & 6.13 \\
$K_{\mathrm{M}}(\mu \mathrm{M})$ & 0.52 & 0.070 & 0.030 \\
$V_{\max }(\mathrm{pmol} /$ & 22.5 & 40.9 & 28.7 \\
$\quad \min \cdot \mathrm{mg}$ & & & \\
$\operatorname{protein)}$ & & 35.1 & 57.4 \\
$\begin{array}{c}\mathrm{CL} \text { in vitro,int } \\
\text { (mL/h/mg }\end{array}$ & 2.6 & & \\
protein) & & & \\
\hline
\end{tabular}

${ }^{a}$ Based on MLogP estimates (with preference given to measured values) in Bio-Loom for Windows. ${ }^{57}$

$\mathrm{CL}_{\text {in vitro,int, }}$ in vitro intrinsic clearance.
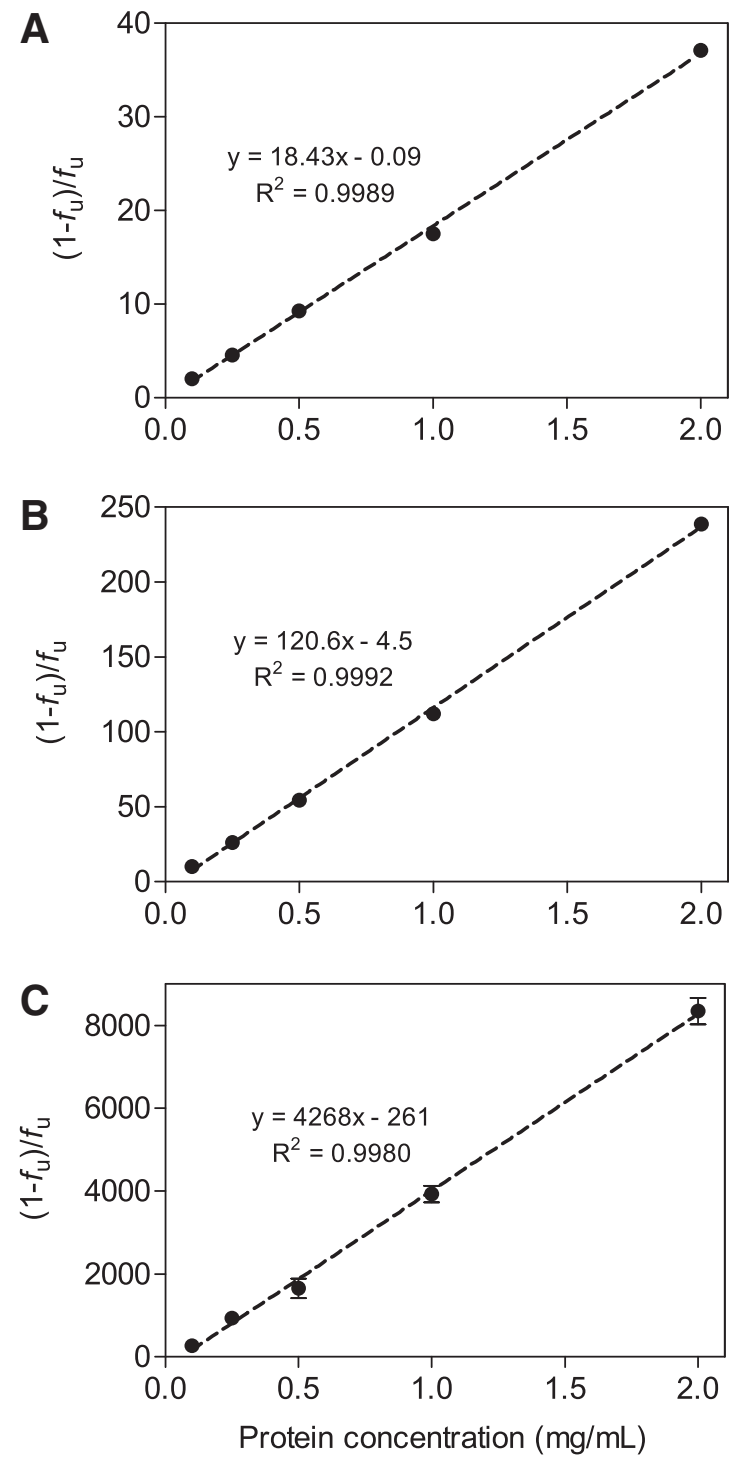

FIG. 6. Binding of PHEN (A), PYR (B), and BAP (C) in trout liver S9 fractions. Data are plotted as the bound-tofree ratio $\left(\left[\left(1-f_{\mathrm{u}}\right) / f_{\mathrm{u}}\right]\right.$ versus $\mathrm{S} 9$ protein concentration. Each point represents the mean \pm SD of 5 (phenanthrene and pyrene) or 7 (BAP) independent determinations. a linear binding relationship was obtained for each compound suggesting that binding was nonspecific and nonsaturable. The measured unbound fractions at the highest tested protein concentration $(2 \mathrm{mg} / \mathrm{mL})$ were $2.6 \pm 0.04 \%, 0.4 \pm$ $0.004 \%$, and $0.012 \pm 0.0004 \%$ for PHEN, PYR, and BAP, respectively.

\section{Effect of S9 protein concentration on in vitro clearance}

The effects of S9 protein concentration on PAH metabolism are shown in Figure 7A-L. Depletion rates $\left(k_{\mathrm{dep}}\right)$ measured for each compound increased with increasing protein concentration and then tended to level off. For any given compound, fitted $k_{\text {dep }}$ values at the three highest protein concentrations $(0.5,1.0$, and $2.0 \mathrm{mg} / \mathrm{mL})$ were essentially the same (Fig. 7A-C). Each $k_{\text {dep }}$ value was divided by the corresponding $\mathrm{S} 9$ protein concentration to calculate an in vitro clearance rate $\left(\mathrm{CL}_{\text {in vitro }} ; \mathrm{mL} / \mathrm{min} \cdot \mathrm{mg}\right.$ protein) normalized for protein content (Fig. 7D-F). These $\mathrm{CL}_{\text {in }}$ vitro values were then divided by the $f_{\mathrm{u}}$ value corresponding to each experiment to calculate a set of unbound in vitro clearance rates $\left(\mathrm{CL}_{\text {in vitro, }} ; \mathrm{mL} / \mathrm{min} \cdot \mathrm{mg}\right.$ protein; Fig. $\left.7 \mathrm{G}-\mathrm{I}\right)$.

Finally, to provide a basis for interpreting these $\mathrm{CL}_{\text {in vitro, }}$ values, the unbound chemical concentration $\left(C_{u}\right)$ at the start of each assay was calculated by multiplying the starting total concentration by the $f_{\mathrm{u}}$ value corresponding to the tested protein concentration (Fig. 7J-L). The dashed line in each of these panels is equal to the $f_{\mathrm{u}}$ value for this compound at $1.0 \mathrm{mg} / \mathrm{mL}$ protein multiplied by the affinity constant $\left(K_{\mathrm{M}}\right)$ determined in earlier concentration dependence studies (Fig. 4). This product term may be viewed as the $\mathrm{C}_{\mathrm{u}}$ associated with half-maximal activity for each of the studied reactions.

Observed declines in $\mathrm{CL}_{\text {in vitro }}$ with increasing $\mathrm{S} 9$ protein concentration were due largely to corresponding decreases in $f_{\mathrm{u}}$ and by extension $\mathrm{C}_{\mathrm{u}}$. By expressing activity in terms of the unbound clearance, it was possible to correct for these changes. Calculated $\mathrm{CL}_{\text {in }}$ vitro, u values for PHEN declined slightly with increasing $\mathrm{S} 9$ protein, but varied only $20 \%$ overall. In contrast, there were clear reductions in $\mathrm{CL}_{\text {in vitro, }}$ values for PYR and BAP at the lowest tested protein concentrations. An examination of Figure 7J-L suggests that these reduced levels of turnover can be explained by the fact that $\mathrm{C}_{\mathrm{u}}$ values at these lower protein levels were approaching the $\mathrm{C}_{\mathrm{u}}$ associated with half-maximal enzyme activity (dashed lines). Free concentrations of PHEN at all tested protein concentrations were well below this level.

\section{Discussion}

Hydrophobic environmental contaminants tend to partition out of water and into the tissues of fish and other aquatic organisms. Absent biotransformation, this behavior results in chemical accumulation that may exceed thresholds established by various regulatory authorities, triggering restrictions on chemical production and use. ${ }^{36}$ Standardized in vivo testing procedures are available to directly assess chemical accumulation in fish ${ }^{37}$; however, these methods are expensive, time-consuming, and utilize a substantial number of organisms. The majority of bioaccumulation assessments are therefore performed using predictive massbalance models. ${ }^{38,39}$ Most of the inputs to these models can be predicted reasonably well from a compound's relative 

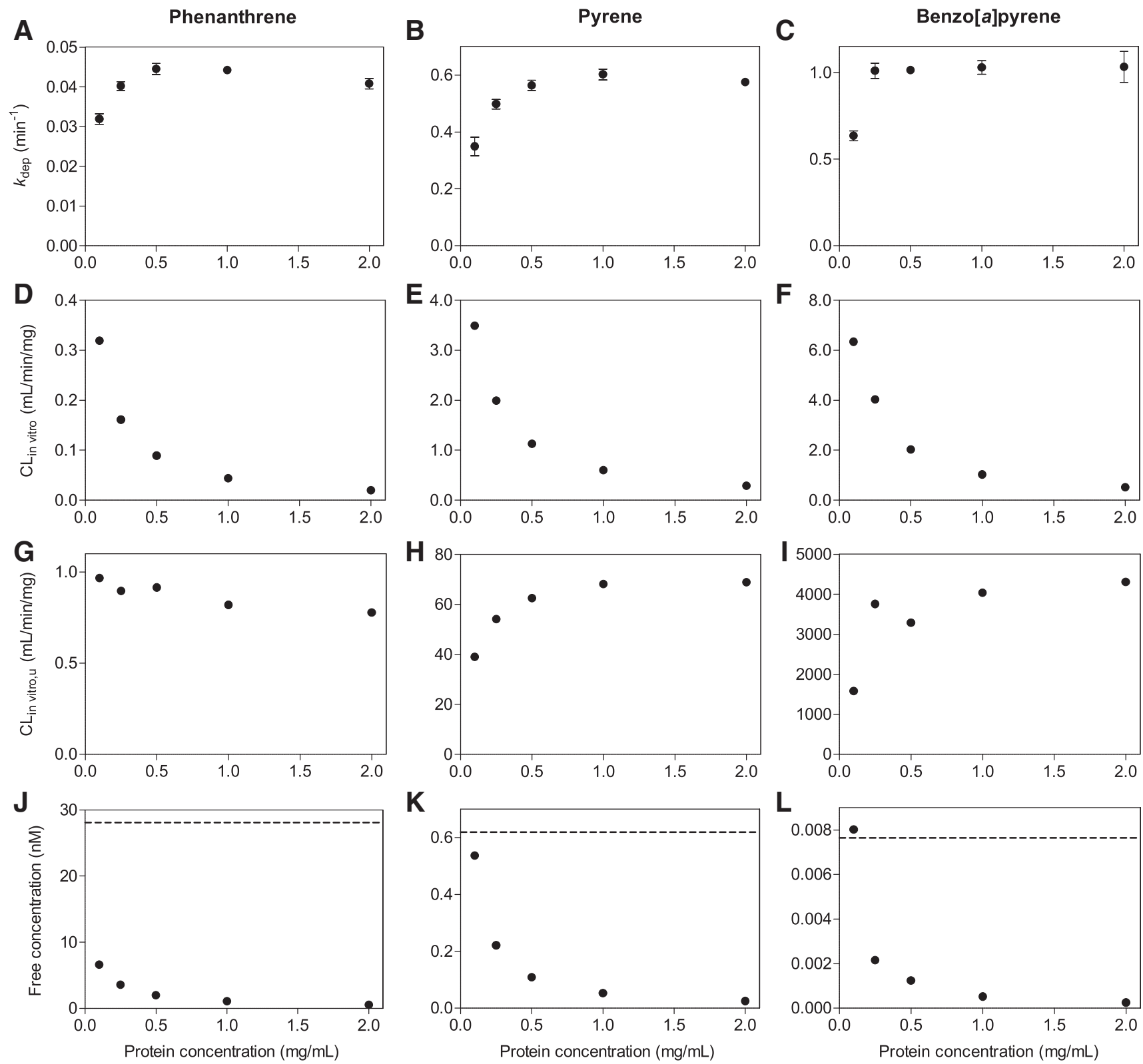

FIG. 7. Effect of trout liver S9 protein concentration on biotransformation of PHEN, PYR, and BAP. Data from substrate depletion studies are expressed in terms of fitted depletion rate constants $\left(k_{\mathrm{dep}} ; \mathbf{A}-\mathbf{C}\right)$, calculated in vitro clearance rates $\left(\mathrm{CL}_{\text {in vitro }} ; \mathbf{D}-\mathbf{F}\right)$, and unbound in vitro clearance rates $\left(\mathrm{CL}_{\text {in vitro, } \mathrm{u}} ; \mathbf{G}-\mathbf{I}\right)$. Reported $k_{\mathrm{dep}}$ estimates represent the mean $\pm \mathrm{SD}$ of values determined in triplicate depletion assays. Free concentrations of each test chemical $(\mathbf{J}-\mathbf{L})$ were calculated using binding relationships shown in Figure 6.

hydrophobicity, typically represented by its $\log K_{\text {ow }}$ value. Unfortunately, biotransformation prediction does not lend itself to this simple approach. It is of interest, therefore, to develop in vitro and in silico methods to estimate wholebody rates of chemical biotransformation as a means of refining modeled bioaccumulation predictions.

Because metabolism rates in fish tend to be lower than those of mammals, we began this study by assessing the working lifetime of the trout S9 preparation. This was done by storing samples for fixed periods of time before starting incubation. These experiments showed that depletion rates were strongly influenced by holding time and suggest that data collected in depletion experiments lasting longer than
30 minutes may be impacted by a progressive loss of enzyme activity. The cause of this decline is not known. Although cofactor depletion is possible, this would not explain why similar changes in activity were observed for chemicals metabolized at very different rates (e.g., PHEN and BAP). Given the crude nature of the $\mathrm{S} 9$ preparation, a more likely explanation is autolytic degradation of metabolizing enzymes. In the present study, EDTA was added to the homogenization buffer to inhibit calcium-dependent proteases and phospholipases. Several authors have added phenylmethylsulfonyl fluoride, a serine protease inhibitor, when isolating liver subcellular fractions from fish. ${ }^{40,41}$ To our knowledge, however, its effectiveness (when used for this application) 
has not been evaluated. Presently, these findings underscore the need to characterize biotransformation based on initial rates of activity and suggest that the $\mathrm{S} 9$ assay is best suited for chemicals that undergo relatively rapid metabolism.

Previous in vitro studies with mammals have shown that spiking solvents used to introduce test compounds can reduce measured levels of CYP activity. ${ }^{42,43}$ These effects are difficult to generalize, however, because different CYPs are impacted to varying degrees by different solvents. In the present study, acetone had less impact on PAH metabolism than ACN; however, acetone levels $>0.5 \%$ had a clear effect on activity. Passive dosing methods have been developed to introduce hydrophobic test chemicals to in vitro biotransformation assays without the use of organic solvents. $^{44,45}$ When these methods were used to investigate PAH metabolism in trout S9 fractions, derived intrinsic clearance rates were close to those obtained by conventional solvent dosing. ${ }^{46}$ Implementation of these passive dosing methods may be complicated, however, by rate limitations imposed by chemical desorption from the partitioning phase, particularly when metabolism rates are rapid, ${ }^{44}$ and requires a validated mathematical model of the dosing system itself.

Researchers who study microsomal UGTs in mammals routinely incorporate a membrane-disrupting agent to remove latency (reduced activity) associated with restricted diffusion of UDPGA across the endoplasmic reticulum. ${ }^{47}$ Alamethicin is preferred for this application, in part, because it is thought to have no impact on microsomal CYP activity. ${ }^{31,32,48}$ In the present study, we evaluated the effect of alamethicin on metabolism of PHEN, which is a likely substrate for trout CYP1A (see below). Alamethicin had a concentration-dependent effect on PHEN depletion, which was evident at alamethicin concentrations commonly employed in research with mammalian microsomal fractions. We retained alamethicin as a component of the assay to preserve its utility for a broad range of substrates, but reduced the amount to $10 \mu \mathrm{g} / \mathrm{mg}$ S9 protein, as this had only a small impact on PHEN metabolism and is still five times greater than the concentration needed to yield maximal UGT activity. ${ }^{26}$

Theory indicates that a biotransformation reaction exhibiting Michaelis-Menten kinetics will yield a log-linear depletion curve when the starting substrate concentration is substantially less than $K_{\mathrm{M}}$. When the starting concentration approaches or exceeds $K_{\mathrm{M}}$, the depletion curve will deviate from linearity if, during the course of the reaction, a decrease in substrate concentration results in a progressive increase in reaction rate. Under such circumstances, a plot of logtransformed depletion data is expected to curve downward.

Depletion curves for PYR and BAP were highly linear at low starting substrate concentrations, but trended downward at several of the higher tested substrate concentrations (Fig. 4). In contrast, log-linear depletion curves were observed for all tested concentrations of PHEN, several of which approached or exceeded the $K_{\mathrm{M}}$ for the reaction (see below). Because PHEN is metabolized at a slower rate than PYR or BAP, these experiments were run for longer periods of time (up to 2 hours). During these longer studies, it is likely that the activity of the system was declining. For a reaction that is run under first-order conditions (i.e., $[\mathrm{S}]<<$ $K_{\mathrm{M}}$ ), this loss of activity might be expected to result in a log-transformed dataset that is linear to start, but flattens out at later time points. At higher substrate concentrations, however, this loss of activity would be counteracted by the increase in depletion rate that occurs as a consequence of declining substrate concentration. Under these circumstances, it would be possible to obtain a linear depletion curve when the starting concentration is well above that which should, in theory, yield this result. These considerations are important because they suggest that the appearance of a log-linear depletion curve does not, by itself, provide clear evidence that a reaction is being performed at a substrate concentration below $K_{\mathrm{M}}$.

When plotted against [S], $k_{\text {dep }}$ values for PHEN, PYR, and BAP described a set of sigmoidal relationships. By fitting Equation (1) to these datasets, we obtained the MichaelisMenten parameters, $K_{\mathrm{M}}$ and $V_{\max }$, for each reaction as well as an estimate of $\mathrm{CL}_{\text {in }}$ vitro,int (i.e., the intrinsic clearance when $\left.k_{\mathrm{dep}([\mathrm{S}] \rightarrow 0)}\right)$. An examination of these derived kinetic parameters indicates that $V_{\max }$ values for all three compounds agreed within a factor of 2 . The primary pathway for biotransformation of PAHs by fish involves hydroxylation of one or more aromatic rings, followed by sulfation and glucuronidation. ${ }^{49}$ These hydroxylation reactions are thought to be catalyzed by CYP1A, although other CYPs (e.g., CYP3A) may contribute. ${ }^{50}$ The observed agreement among $V_{\max }$ values for the three test compounds is consistent with the suggestion that all are metabolized by the same reaction pathway.

In contrast to fitted $V_{\max }$ values, $K_{\mathrm{M}}$ values determined for the three compounds differed by a factor of 17 and varied inversely with chemical $\log K_{\text {ow }}$. Previously, Nichols et al. ${ }^{28}$ found that in vitro clearance rates for six PAHs in trout S9 fractions correlated positively with chemical $\log K_{\text {ow }}$. Additional studies cited by these authors indicate that this pattern is generalizable to PAH metabolism by fish. The data collected by Nichols et al. ${ }^{28}$ were insufficient to determine whether $\log K_{\mathrm{ow}}$-dependent differences in clearance were due to differences in $V_{\max }, K_{\mathrm{M}}$, or both. Based on the present work, it appears that these differences are due largely to differences in $K_{\mathrm{M}}$ and not $V_{\text {max }}$. As such, the results suggest that chemical hydrophobicity is an important determinant of PAH binding to the enzyme(s) responsible for their metabolism in trout. The importance of hydrophobicity as a determinant of chemical binding to mammalian CYPs has been noted by several authors, particularly for CYPs that have evolved to metabolize hydrophobic substrates (e.g., CYP3A4). ${ }^{51}$

An important consideration when extrapolating in vitro biotransformation data to the intact tissue is the extent of chemical binding in vitro and in vivo. Under first-order conditions (i.e., when $[\mathrm{S}]<<K_{\mathrm{M}}$ ), the rate of metabolism is generally assumed to be proportional to the unbound chemical concentration. While some have questioned whether this free chemical hypothesis adequately represents the dynamic environment that exists in liver tissue, this assumption is central to current in vitro-in vivo extrapolation methodologies.

To investigate binding effects on in vitro metabolism, we measured PAH binding across a range of S9 protein concentrations. When the data were plotted as the bound/free ratio versus protein concentration, we obtained a set of linear binding relationships (Fig. 6). The proportional nature of this binding can be shown by dividing the bound/free ratio 
for each compound by the S9 protein concentration, which results in a set of characteristic binding relationships. For PHEN, PYR, and BAP, these normalized binding ratios (mean \pm SD, $n=5$ ) are $18.65 \pm 1.01,109.4 \pm 6.9$, and $3556.7 \pm$ 604.3 , respectively. Furthermore, when these normalized binding ratios are log-transformed and regressed against chemical $\log K_{\mathrm{ow}}$, a linear equation is obtained, which relates S9 binding to chemical hydrophobicity: $\log \left(1-f_{\mathrm{u}} / f_{\mathrm{u}}\right)=1.33 \log K_{\text {ow }}$ $-4.6\left(r^{2}=0.99\right)$. From this relationship, we can derive a general equation, which predicts $\mathrm{S} 9$ binding as a function of chemical $\log K_{\mathrm{ow}}$ and $\mathrm{S} 9$ protein concentration $\left(\mathrm{C}_{\mathrm{S} 9} ; \mathrm{mg} / \mathrm{mL}\right)$ : $\left(1-f_{\mathrm{u}}\right) / f_{\mathrm{u}}=\mathrm{C}_{\mathrm{S} 9} \times 10^{1.33} \log K_{\text {ow }}-4.6$. Issues related to equilibration time and protein carryover limit application of the vial equilibration method to chemicals with $\log K_{\text {ow }}$ values $<6.5$. Nevertheless, the high quality of this derived relationship suggests that binding predictions for more hydrophobic PAHs can be obtained by extrapolating data collected for lower $\log K_{\mathrm{ow}}$ chemicals.

Substrate depletion data collected across a range of S9 protein concentrations clearly illustrate the importance of in vitro chemical binding. At higher protein concentrations, $\mathrm{CL}_{\text {in vitro, }}$ values for each compound were essentially unchanged, indicating that the rate of biotransformation was controlled by the unbound chemical concentration. Similar observations have been made previously for metabolism of highly bound drugs by rat microsomal fractions. ${ }^{52}$ Lower rates of $\mathrm{CL}_{\text {in vitro, }}$ were obtained for PYR and BAP at low S9 protein concentrations. However, these observations may be explained by the fact that unbound chemical concentrations were approaching those associated with saturation of enzyme activity (dashed lines in Fig. 7J-L).

For a hydrophilic substrate dissolved in the aqueous phase of an in vitro metabolizing system, an increase in protein concentration (S9 or microsomal assay) or cell number (hepatocyte assay) would be expected to result in a proportional increase in $k_{\mathrm{dep}}$ and little or no change in $\mathrm{CL}_{\text {in }}$ vitro and $\mathrm{C}_{\text {in vitro, } \mathrm{u}}$. This would increase the sensitivity of the assay, defined as its ability to detect biotransformation (i.e., a depletion rate significantly different from that of negative controls) within a fixed period of time. For a hydrophobic compound, increasing the protein concentration or cell number does not increase the assay's sensitivity because the increase in the amount of enzyme present is offset by a decrease in unbound substrate concentration. A decrease in protein concentration or cell number may, however, drive the assay into a range where $k_{\text {dep }}$ is impacted by unbound substrate concentrations that approach or exceed $K_{\mathrm{M}}$. For such compounds, we may expect an optimal protein or cell concentration, which results in maximal activity while limiting the required amount of biological material. In the present study, the optimal amount of S9 protein for all three PAHs was $1 \mathrm{mg} / \mathrm{mL}$.

\section{Implications for use of S9 assay data in bioaccumulation assessments for fish}

The results of this study have important implications for use of S9 assay data in bioaccumulation assessments for fish. Proponents of this approach have pointed out that liver S9 fractions are easier to prepare and use than microsomes or isolated hepatocytes. ${ }^{28}$ This is an important consideration if the goal is to develop methods that can be adapted to a large number of different fish species. On the other hand, the short working lifetime of this preparation may impose a lower limit on the rate of activity that can be accurately quantified. Previously, Nichols et al. ${ }^{28}$ estimated this lower limit on $k_{\text {dep }}$ to be about $0.05 / \mathrm{h}$ based on historical data for several slowly metabolized substances. A somewhat higher limit value $(0.14 / \mathrm{h})$ was estimated by Chen et al. ${ }^{53}$ based on modeled simulations of hypothetical substrate depletion data. The actual limit will depend on the quality of the dataset (e.g., the precision of replicated measurements at each time point) and the behavior of negative controls, as well as the stability of the preparation.

Substrate depletion experiments conducted with the goal of measuring intrinsic hepatic clearance should be performed under first-order reaction conditions (concentration $<<K_{\mathrm{M}}$ ). With respect to bioaccumulation assessments, such a study would provide a conservative basis for assessing metabolism impacts on chemical accumulation in fish; that is, if the highest measured rate of activity does not reduce the predicted level of accumulation below a threshold level for regulatory action, lower levels of activity could only result in higher predicted values. The present study shows, however, that log-linear depletion curves can be obtained across a wide range of substrate concentrations, including those well above $K_{\mathrm{M}}$. The existence of a well-behaved log-linear curve may be insufficient, therefore, to establish the existence of true first-order conditions. Instead, the results of this study underscore the need to evaluate the concentration dependence of activity, particularly for high $\log K_{\text {ow }}$ compounds.

Several studies have shown that in vitro metabolism data can be used to refine modeled predictions of chemical accumulation in fish. In general, however, there is a trend toward overestimation of measured accumulation (e.g., steady-state $\mathrm{BCFs}$ ) even when these in vitro findings are taken into account. Examples include studies performed by CowanEllsberry et al. ${ }^{6}$ and Han et al. ${ }^{10}$ The results of the present effort suggest that one reason for these discrepancies has been the past use of inappropriately high starting substrate concentrations. The $K_{\mathrm{M}}$ value determined here for BAP metabolism was $0.03 \mu \mathrm{M}$. For comparison, Han et al. ${ }^{10}$ used starting substrate concentrations of 2 or $5 \mu \mathrm{M}(2 \mu \mathrm{M}$ for BAP), while Cowan-Ellsberry et al. ${ }^{6}$ evaluated four compounds at a starting concentration of $10 \mu \mathrm{M}$ (S9 studies). The likely overestimation of measured BCFs by previous authors due to the use of high starting substrate concentrations was also noted in a recent study by Lo et al. ${ }^{46}$

Ultimately, the choice of an appropriate starting concentration for in vitro metabolism studies may be best informed by exposures that fish experience in the wild. Measured concentrations of PHEN, PYR, and BAP in surface water may approach $500 \mathrm{ng} / \mathrm{L}$; however, most reported values are $<50 \mathrm{ng} / \mathrm{L},{ }^{54-56}$ even for relatively contaminated sites. In a prolonged exposure, the unbound chemical concentration in a fish will approach the total concentration in water, assuming that the fish is exposed to the chemical in water only, there is little binding in the water (e.g., to dissolved organic carbon), and the rate of biotransformation is negligible. To relate this unbound concentration to a total concentration employed in an in vitro assay, it is necessary to correct for binding in the assay itself. For example, binding data for PYR suggest that the unbound chemical fraction at $1 \mathrm{mg} / \mathrm{mL}$ 
S9 protein is $\sim 0.009$. Dividing this figure into $0.247 \mathrm{nM} \mathrm{PYR}$ (equivalent to an aqueous concentration of $50 \mathrm{ng} / \mathrm{L}$ ) gives a value of $0.027 \mu \mathrm{M}$. Thus, under the assumed circumstances, an environmental exposure to $50 \mathrm{ng} / \mathrm{L}$ PYR would equate to a total PYR concentration in the S9 assay of $0.027 \mu \mathrm{M}$, which is less than the measured $K_{\mathrm{M}}$ for PYR $(0.07 \mu \mathrm{M})$, although not markedly so.

Additional insight may be gained by considering standardized in vivo laboratory exposures used to measure chemical bioconcentration in fish. In the absence of more specific modes of action, neutral organic compounds will exert a lethal effect due to acute narcosis. ${ }^{57}$ This baseline toxicity can be associated with a critical body residue (CBR), which tends to be remarkably constant across a wide range of chemical structures. For PAHs, the average CBR associated with acute narcosis in fish is about $2 \mathrm{mmol} / \mathrm{kg}$ wet wt. ${ }^{57}$ Absent biotransformation, the BCF may be estimated as the product of a fish's fractional lipid content and a compound's $K_{\mathrm{ow}}$ value. For example, the reported $\log K_{\text {ow }}$ value for PYR is $4.88 .{ }^{58}$ Based on this value, the estimated $\mathrm{BCF}$ for a fish that contains $5 \%$ lipid is 3792 (i.e., $0.05 \times 10^{4.88}$ ). Dividing this BCF into the CBR for acute narcosis of PAHs, the aqueous concentration of PYR expected to elicit toxicity is $0.53 \mu \mathrm{M}$.

Because the goal of an in vivo bioconcentration test is to measure chemical accumulation under conditions that do not result in toxicity, tested aqueous concentrations will be lower than this value. However, given the need to control and characterize these exposures, experiments conducted at concentrations 1/100th the lethal level are not unexpected. In the hypothetical case described here, this would result in a PYR test concentration of $5.3 \mathrm{nM}$, which is 20 times greater than PAH concentrations associated with high environmental exposures (i.e., $5.3 \mathrm{nM} / 0.247 \mathrm{nM}$ ).

These comparisons do not account for the impact of metabolism on PYR accumulation by fish. This activity will reduce PYR concentrations throughout the animal and may have a profound impact within the liver tissue itself. As such, it will tend to drive the system toward a condition that is less likely to saturate. Similar calculations for BAP and other higher $\log K_{\mathrm{ow}}$ compounds are complicated by the greater likelihood of chemical uptake from dietary sources as well as binding in the exposure water. Nevertheless, these comparisons suggest that enzymes responsible for PAH metabolism in fish may approach saturation at some highly contaminated sites and are even more likely to saturate in standardized in vivo BCF testing efforts. This second outcome is of special interest because it suggests the possibility that in vivo test results could exhibit concentration dependence and/or reflect a greater degree of accumulation than actually occurs in a natural setting.

Research is needed to determine whether the present study findings can be generalized to other chemical classes and reaction pathways. A need also exists for computational models that can be used to relate in vitro clearance observations to measured or predicted in vivo exposures. Because they describe the chemical concentration-time course in specific tissues, physiologically toxicokinetic models for fish may be well suited for this purpose. To date, however, most of the research conducted to support the development of such models has been performed using poorly metabolized compounds. ${ }^{59-61}$ Additional studies involving in vivo exposures to compounds that undergo substantial metabolism are re- quired. Ideally, such efforts would be accompanied by tissuespecific analysis of chemical residues as well as in vitro measurement of biotransformation using biological material collected from the same group of animals.

\section{Acknowledgment}

The authors gratefully acknowledge Philipp Mayer and Dorothea Gilbert for instruction on use of the vial equilibration method to measure free and bound chemical concentrations, and for supplying vials used to make the S9 binding measurements.

\section{Author Disclosure Statement}

No competing financial interests exist.

\section{References}

1. Iwatsubo T, Hirota N, Ooie $\mathrm{T}$, et al. Prediction of in vivo drug disposition from in vitro data based on physiological pharmacokinetics. Biopharm Drug Dispos 1996:17;273310.

2. Houston JB, Carlile DJ. Prediction of hepatic clearance from microsomes, hepatocytes and liver slices. Drug Metab Rev 1997:29;891-922.

3. Obach RS, Baxter JG, Liston TE, et al. The prediction of human pharmacokinetic parameters from preclinical and in vitro metabolism data. J Pharmacol Exp Ther 1997:283; 46-58.

4. Obach RS, Reed-Hagen AE. Measurement of Michaelis constants for cytochrome P450-mediated biotransformation reactions using a substrate depletion approach. Drug Metab Dispos 2002:30;831-837.

5. Nichols JW, Schultz IR, Fitzsimmons PN. In vitro-in vivo extrapolation of quantitative hepatic biotransformation data for fish. I. A review of methods, and strategies for incorporating intrinsic clearance estimates into chemical kinetic models. Aquat Toxicol 2006:78;74-90.

6. Cowan-Ellsberry CE, Dyer SD, Erhardt S, et al. Approach for extrapolating in vitro metabolism data to refine bioconcentration factor estimates. Chemosphere 2008:70;18041817.

7. Southworth GR, Keffer CC, Beauchamp JJ. Potential and realized bioconcentration. A comparison of observed and predicted bioconcentration of azaarenes in the fathead minnow (Pimephales promelas). Environ Sci Technol 1980: $14 ; 1529-1531$.

8. Oliver BG, Niimi AJ. Bioconcentration factors of some halogenated organics for rainbow trout: limitations in their use for prediction of environmental residues. Environ Sci Technol 1985:19;842-849.

9. de Wolf W, de Bruijn JHM, Seinen W, et al. Influence of biotransformation on the relationship between bioconcentration factors and octanol-water partition coefficients. Environ Sci Technol 1992:26;1197-1201.

10. Han X, Nabb DL, Mingoia RT, et al. Determination of xenobiotic intrinsic clearance in freshly isolated hepatocytes from rainbow trout (Oncorhynchus mykiss) and rat and its application in bioaccumulation assessment. Environ Sci Technol 2007:41;3269-3276.

11. Dyer SD, Bernhard MJ, Cowan-Ellsberry C, et al. In vitro biotransformation of surfactants in fish. Part I: linear alkylbenzene sulfonate (C12-LAS) and alcohol ethoxylate (C13EO8). Chemosphere 2008:72;850-862. 
12. Han X, Nabb DL, Yang C-H, et al. Liver microsomes and S9 from rainbow trout (Oncorhynchus mykiss): comparison of basal-level enzyme activities with rat and determination of xenobiotic intrinsic clearance in support of bioaccumulation assessment. Environ Toxicol Chem 2009:28; 481-488.

13. Gomez CF, Constantine L, Huggett DB. The influence of gill and liver metabolism on the predicted bioconcentration of three pharmaceuticals in fish. Chemosphere 2010:81; 1189-1195.

14. Laue H, Gfeller H, Jenner KJ, et al. Predicting the bioconcentration of fragrance ingredients by rainbow trout using measured rates of in vitro intrinsic clearance. Environ Sci Technol 2014:48;9486-9495.

15. Escher BI, Cowan-Ellsberry CE, Dyer S, et al. Protein and lipid binding parameters in rainbow trout (Oncorhynchus mykiss) blood and liver fractions to extrapolate from an in vitro metabolic degradation assay to in vivo bioaccumulation potential of hydrophobic organic chemicals. Chem Res Toxicol 2011:24;1134-1143.

16. Nichols JW, Bonnell M, Dimitrov SD, et al. Bioaccumulation assessment using predictive approaches. Integr Environ Assess Manag 2009:5;577-597.

17. Chu X, Korzekwa K, Elsby R, et al. Intracellular drug concentrations and transporters: measurement, modeling, and implications for the liver. Clin Pharmacol Ther 2013:94; 126-141.

18. Gomez JM, Mourot B, Fostier A, et al. Growth hormone receptors in ovary and liver during gametogenesis in female rainbow trout (Oncorhynchus mykiss). J Reprod Fertil 1999:115;275-285.

19. Le Gac F, Thomas JL, Mourot B, et al. In vivo and in vitro effects of prochloraz and nonylphenol ethoxylates on trout spermatogenesis. Aquat Toxicol 2001:53;187-200.

20. Förlin L, Haux C. Sex differences in hepatic cytochrome P450 monooxygenase activities in rainbow trout during an annual reproductive cycle. J Endocrinol 1990:124;207-213.

21. Fay KA, Fitzsimmons PN, Hoffman AD, et al. Optimizing the use of rainbow trout hepatocytes for bioaccumulation assessments with fish. Xenobiotica 2014:44;345-351.

22. Johanning K, Hancock G, Escher B, et al. Assessment of metabolic stability using the rainbow trout (Oncorhynchus mykiss) liver S9 fraction. Curr Protoc Toxicol 2012:53; 14.10.1-14.10.28.

23. Kleinow KM, Haasch ML, Lech JJ. The effect of tricaine anesthesia upon induction of select P-450 dependent monooxygenase activities in rainbow trout (Salmo gairdneri). Aquat Toxicol 1986:8;231-241.

24. Kolanczyk RC, Fitzsimmons PN, McKim JM, Sr., et al. Effects of anesthesia (tricaine methanesulfonate, MS222) on liver biotransformation in rainbow trout (Oncorhynchus mykiss). Aquat Toxicol 2003:64;177-184.

25. Burke MD, Mayer RT. Ethoxyresorufin: direct fluorimetric assay of a microsomal O-dealkylation which is preferentially inducible by 3-methylcholanthrene. Drug Metab Dispos 1974:2;583-588.

26. Ladd MA, Fitzsimmons PN, Nichols JW. Optimization of a UDP-glucuronosyltransferase assay for trout liver S9 fractions: activity enhancement by alamethicin, a pore-forming peptide. Xenobiotica 2016:46;1066-1075.

27. Habig WH, Pabst MJ, Jakoby WB. Glutathione Stransferases. The first enzymatic step in mercapturic acid formation. J Biol Chem 1974:249;7130-7139.
28. Nichols JW, Hoffman AD, ter Laak TL, et al. Hepatic clearance of 6 polycyclic aromatic hydrocarbons by isolated perfused trout livers: prediction from in vitro clearance by liver S9 fractions. Toxicol Sci 2013:136;359-372.

29. Matsubara T, Koike M, Touchi A, et al. Quantitative determination of cytochrome P-450 in rat liver homogenate. Anal Biochem 1976:75;596-603.

30. Nichols JW, Huggett DB, Arnot JA, et al. Toward improved models for predicting bioconcentration of well-metabolized compounds by rainbow trout using measured rates of in vitro intrinsic clearance. Environ Toxicol Chem 2013: 32;1611-1622.

31. Fisher MB, Campanale $\mathrm{K}$, Ackermann $\mathrm{BL}$, et al. In vitro glucuronidation using human liver microsomes and the pore-forming peptide alamethicin. Drug Metab Dispos 2000:28;560-566.

32. Walsky RL, Bauman JN, Bourcier K, et al. Optimized assays for human UDP-glucuronosyltransferase (UGT) activities: altered alamethicin concentration and utility to screen for UGT inhibitors. Drug Metab Dispos 2012:40;10511065.

33. Birch H, Gouliarmou V, Lützhøft $\mathrm{H}-\mathrm{CH}$, et al. Passive dosing to determine the speciation of hydrophobic organic chemicals in aqueous samples. Anal Chem 2010:82;11421146.

34. Gouliarmou V, Smith KEC, de Jonge LW, et al. Measuring binding and speciation of hydrophobic organic chemicals at controlled freely dissolved concentrations and without phase separation. Anal Chem 2012:84;1601-1608.

35. Nath A, Atkins WM. A theoretical validation of the substrate depletion approach to determining kinetic parameters. Drug Metab Dispos 2006:34;1433-1435.

36. Gobas FAPC, de Wolf W, Burkhard LP, et al. Revisiting bioaccumulation criteria for POPs and PBT assessments. Integr Environ Assess Manag 2009:5;624-637.

37. OECD Guidelines for testing of chemicals. Test no. 305. Bioaccumulation in fish: aqueous and dietary exposure, last updated October 2, 2012. Paris: OECD Publishing; 2012.

38. Arnot JA, Gobas FAPC. A generic QSAR for assessing the bioaccumulation potential of organic chemicals in aquatic food webs. QSAR Comb Sci 2003:22;337-345.

39. Arnot JA, Gobas FAPC. A food web bioaccumulation model for organic chemicals in aquatic ecosystems. Environ Toxicol Chem 2004:23;2343-2355.

40. James MO, Altman AH, Morris K, et al. Dietary modulation of phase 1 and phase 2 activities with benzo[a]pyene and related compounds in the intestine but not the liver of the channel catfish, Ictalurus punctatus. Drug Metab Dispos 1997: 25;346-354.

41. McElroy AE, Kleinow KM. In-vitro metabolism of benzo[a]pyrene and benzo[a]pyrene-7,8-dihydrodiol by liver and intestinal mucosa homogenates from the winter flounder (Pseudopleuronectes americanus). Mar Environ Res 1992:34;279-285.

42. Hickman D, Wang J-P, Wang Y, et al. Evaluation of the selectivity of in vitro probes and suitability of organic solvents for the measurement of human cytochrome P450 monooxygenase activities. Drug Metab Dispos 1998:26;207-215.

43. Chauret N, Gauthier A, Nicoll-Griffith DA. Effect of common organic solvents on in vitro cytochrome P450-mediated metabolic activities in human liver microsomes. Drug Metab Dispos 1998:26;1-4. 
44. Lee Y-S, Otton SV, Campbell DA, et al. Measuring in vitro biotransformation rates of super hydrophobic chemicals in rat liver S9 fractions using thin-film sorbent-phase dosing. Environ Sci Technol 2012:46;410-418.

45. Lee Y-S, Lee DHY, Delafoulhouze M, et al. In vitro biotransformation rates in fish liver S9: effect of dosing techniques. Environ Toxicol Chem 2014:33;1885-1893.

46. Lo JC, Allard GN, Otton SV, et al. Concentration dependence of biotransformation in fish liver S9: optimizing substrate concentrations to estimate hepatic clearance for bioaccumulation assessment. Environ Toxicol Chem 2015: 34;2782-2790.

47. Fulceri R, Bánhegyi G, Gamberucci A, et al. Evidence for the intraluminal positioning of $p$-nitrophenol UDPglucuronosyltransferase activity in rat liver microsomal vesicles. Arch Biochem Biophys 1994:309;43-46.

48. Kilford PJ, Stringer R, Sohal B, et al. Prediction of drug clearance by glucuronidation from in vitro data: use of combined cytochrome P450 and UDP-glucuronosyltransferase cofactors in alamethicin-activated human liver microsomes. Drug Metab Dispos 2009:37;82-89.

49. Varanasi U, Stein JE, Nishimoto M. Biotransformation and disposition of polycyclic aromatic hydrocarbons (PAH) in fish. In: Metabolism of Polycyclic Aromatic Hydrocarbons in the Aquatic Environment. U Varanasi (ed); pp. 93-150. Boca Raton, FL: CRC Press; 1989.

50. Schlenk D, Celander M, Gallagher E, et al. Biotransformation in fishes. In: The Toxicology of Fishes. RT Di Giulio, DE Hinton (eds); pp. 153-234. Boca Raton, FL: CRC Press; 2008.

51. Long A, Walker JD. Quantitative structure-activity relationships for predicting metabolism and modeling cytochrome P450 enzyme activities. Environ Toxicol Chem 2003:22; 1894-1899.

52. Austin RP, Barton P, Cockroft SL, et al. The influence of nonspecific microsomal binding on apparent intrinsic clearance, and its prediction from physicochemical properties. Drug Metab Dispos 2002:30;1497-1503.

53. Chen Y, Hermens JLM, Jonker MTO, et al. Which molecular features affect the intrinsic hepatic clearance rate of ionizable organic chemicals in fish? Environ Sci Technol 2016:50;12722-12731.
54. Manoli E, Samara C. Polycyclic aromatic hydrocarbons in natural waters: sources, occurrence and analysis. Trends Anal Chem 1999:18;417-428.

55. Zhang S, Zhang Q, Darisaw S, et al. Simultaneous quantification of polycyclic aromatic hydrocarbons (PAHs), polychlorinated biphenyls (PCBs), and pharmaceuticals and personal care products (PPCPs) in Mississippi river water, in New Orleans, Louisiana, USA. Chemosphere 2007:66;10571069.

56. Xia X, Zhai Y, Dong J. Contribution ratio of freely to total dissolved concentrations of polycyclic aromatic hydrocarbons in natural river waters. Chemosphere 2013:90;17851793.

57. McCarty LS, Arnot JA, Mackay D. Evaluation of critical body residue data for acute narcosis in aquatic organisms. Environ Toxicol Chem 2013:32;2301-2314.

58. Bio-Loom for Windows, Version 1.5, 2011. CLogP V5.0, www.BioByte.com. BioByte Corp., Claremont, CA.

59. Nichols JW, McKim JM, Andersen ME, et al. A physiologically based toxicokinetic model for the uptake and disposition of waterborne organic chemicals in fish. Toxicol Appl Pharm 1990:106;433-447.

60. Stadnicka J, Schirmer K, Ashauer R. Predicting concentrations of organic chemicals in fish using toxicokinetic models. Environ Sci Technol 2014:46;3273-3280.

61. Brinkman M, Schlechtriem C, Reininghaus M, et al. Crossspecies extrapolation of uptake and disposition of neutral organic chemicals in fish using a multispecies physiologicallybased toxicokinetic model framework. Environ Sci Technol 2016:50;1914-1923.

Address correspondence to: Dr. John W. Nichols National Health and Environmental Effects Research Laboratory Mid-Continent Ecology Division US Environmental Protection Agency Office of Research and Development 6201 Congdon Boulevard Duluth, MN 55804

E-mail: nichols.john@epa.gov 